\title{
ОБУЧЕНИЕ РУССКОМУ ЯЗЫКУ КИТАЙСКИХ СТУДЕНТОВ-ФИЛОЛОГОВ: ГРАММАТИЧЕСКИЙ АСПЕКТ
}

\section{TEACHING RUSSIAN LANGUAGE TO CHINESE PHILOLOGY STUDENTS: A GRAMMATIC ASPECT}

\section{Wang Yameng}

Summary: The assimilation of grammatical structure is a necessary prerequisite for the formation of foreign language consciousness. The nature of the Russian and Chinese languages is completely different, so the problem of mastering Russian grammar is especially relevant for the Chinese audience. To improve the skills of the grammar processing of the Russian speech it is necessary to identify the functional and semantic features of the Russian case forms in relation to the Chinese grammar forms in order to prevent errors caused by interference.

Keywords: grammatical system, language, consciousness, interference.
Л обая методология требует разработки принципов и приемов обучения. Принципы обучения - это правила и направления, соблюдение которых делает процесс обучения эффективным [1: с.132]. На основе принципов обучения разрабатываются приемы, к которым, прежде всего, относятся методы объяснения материала и сложность упражнений.

Изучение иностранных языков имеет несколько аспектов. Один из них - грамматика. Она играет важную роль в обучении говорению на другом языке, являясь своего рода каркасом, на котором строится словарный запас. Изучение грамматики, а также формирование предложений и распознавание грамматических форм в устной и письменной речи, осуществляется путем формирования грамматических навыков.

Грамматика имеет очень важное значение в процессе обучения и формирования практических навыков использования иностранного языка. Очевидно, что ни один аспект изучения языка не вызывал столько споров и дискуссий на протяжении многих лет. Грамматика играет неодинаковую роль не только в изучении родного и иностранного языков, но и в системах образования разных стран [2; с.4].

В последние десятилетия двадцатого века коммуникативный аспект изучения русского языка как иностранного был признан во всем мире. Соотношение содержания грамматики и коммуникативной цели обучения является одной из основных проблем в коммуникатив-
Аспирант, Московский Педагогический Государственный Университет, Москва

Tamefor@bk.ru

Аннотация: Усвоение грамматического строя является необходимой предпосылкой формирования иноязычного языкового сознания. Природа русского и китайского языков совершенно различна, поэтому проблема усвоения русской грамматики особенно актуальна для китайской аудитории. Для совершенствования навыков грамматической обработки русской речи необходимо выявить функционально-семантические особенности русских падежных форм по отношению к китайским грамматическим формам с целью предупреждения ошибок, вызванных интерференцией.

Ключевые слова: грамматическая система, язык, сознание, интерференция.

но-ориентированном курсе русского языка. Коммуникативные навыки включают в себя умелое использование языкового материала при производстве или получении информации. Однако в некоторых курсах преподавания русского языка отсутствует грамматический аспект, хотя исследованиями в области психолингвистики, теории речевых актов, когнитивной психологии установлено, что возможность практического использования языка в общении основывается на способности человека совершать речевые акты, опираясь на знание программы речевого акта, а также на знание использования языковых средств и языкового материала при реализации речевого намерения в различные ситуации. Здесь грамматические правила имеют большое значение в реализации способности человека к речевому творчеству.

Опыт преподавания русского языка на факультете русского языка Шэньян Лигун Университета показывает, что студенты первого курса испытывают большие трудности в усвоении грамматики. Это связано с тем, что почти 90\% студентов, поступающих в университет, не изучали русский язык в начальной школе, поэтому им очень трудно овладеть русской грамматикой. Тем не менее, мы еще раз подчеркнем, что грамматика является необходимой основой для правильного использования языка как средства общения.

Языковые навыки являются важным компонентом содержания изучения русского языка как иностранного, так как включают в себя способность выразить мысль и понять высказывание на основе знания и использования 
языковых средств. Грамматический навык описывается как один из речевых навыков, автоматическое действие или операция с грамматическим материалом.

Хорошо известно, что грамматика - это сложный мультиплексный объект, огромное количество объектов для усвоения учеником, каждый из которых требует особый метод представления и обработки. Более того, грамматика тесно связана с лексикой и фонетикой. Поэтому грамматическая ошибка часто является также фонетической или лексической. Взаимосвязь грамматики, лексики и фонетики учитывается в аспектуально-композиционном принципе работы с грамматическим материалом.

С середины двадцатого века были созданы новые методы представления грамматики, отражающие практические цели изучения и помогающие преодолеть формальный подход. Функционально-семантический принцип - один из важнейших. Согласно ему, материал организуется "из идей, стремящихся быть выраженными" [3; с.65] и направлен на реализацию речевого намерения (коммуникативной цели). Этот принцип требует изложения материала на синтаксической основе. В качестве такой основы обычно используется конструкция предложения, схема структуры текстовой единицы (в диалоге или монологе). Конструкция наполняется типичным лексико-морфологическим содержанием, образуя речевой паттерн. Вариации наполнения речевого образца стимулируют автоматизацию использования форм и конструкций, а также обобщение отдельных языковых закономерностей, что составляет основу правила.

Практика преподавания русского языка китайским студентам и немногочисленные исследования на эту тему позволяют утверждать, что наибольшее количество систематических ошибок допускается в процессе фонетического, грамматического и синтаксического оформления речи на русском языке в силу лингвистических и экстралингвистических факторов. В основном это связано с негативным влиянием родного языка (интерференцией), ведь, как известно, китайский и русский языки не являются генетически родственными и представляют собой типологически разные системы. В китайском языке нет форм лица, времени, рода, числа и падежа, а порядок слов играет значительную роль. Отсутствие падежной системы может выступать в качестве одной из основных причин.

Известно, что специфическими особенностями русского языка являются инфлективный характер всей языковой системы и сочетание флективных словоизменительных форм с предлогами, сложная аспектуальновременная глагольная система, особенности словообразовательных связей, сочетаемости слов и предложений, порядок слов и ритмико-речевое оформление предложений. Эти специфические особенности особенно ак- туальны для китайских студентов, изучающих русский язык. Китайский язык, в отличие от русского, имеет номинативную структуру и грамматически важный порядок слов, предлог атрибута, агглютинативную структуру: нет категорий пола, лица, падежа, числа, используемых с инфиксами, нет предлогов. Как утверждает Тань Аошуан, китайская грамматическая система "не открыта" для непосредственного наблюдения из-за слогово-морфемной формы ее основной словесной единицы и отсутствия внутренней инфлексии [4; с.72]. Кроме того, в русских и китайских словосочетаниях используются специфические средства грамматической связи. Не секрет, что "знание средств грамматической связи и навыки использования грамматических категорий необходимы для владения языком" [5; с.77]. Все это определяет сложность изучения русской грамматики китайскими студентами и требует решения многих вопросов по методике, ведущих к совершенствованию методики преподавания русского языка в китайской аудитории.

Работа по формированию и совершенствованию правильных и устойчивых речевых грамматических навыков, в частности, русского падежа, более эффективна, если проводится на основе сопоставления двух языков и методики обучения конкретным навыкам.

Процесс обучения не в языковой среде, несомненно, имеет свои особенности, ведь формирование речевых навыков определяется только учебной моделью. Конечный результат в основном зависит от того, насколько модель способствует достижению цели и помогает использовать языковую и коммуникативную компетенцию в реальных ситуациях общения. Однако тот факт, что иноязычная речевая деятельность ограничена рамками аудитории, вне которой учащиеся пользуются родным языком, а преподаватель, как правило, не является носителем языка, не обеспечивает должных условий для автоматизации языковых и речевых навыков и серьезно влияет на формирование грамматических навыков [6; с.46]. Ярким примером является грамматическая структура предложения на русском языке, продуцируемая китайскими студентами.

Мы предполагаем, что усвоение грамматического строя иностранного языка является необходимой предпосылкой для формирования языкового сознания, так как беглой речевой деятельности можно научить только после изучения грамматических особенностей языка. Усвоение речевых норм возможно только на основе учебно-речевой ситуации, что предполагает ряд условий для стимулирования речевой деятельности по теме, включающей определенные грамматические средства. Это особенно актуально для взрослой аудитории, где при обучении грамматическому строю используется рационально-активное сравнение языковых особенностей (в нашем случае китайско-русского). 
Процесс распознавания требует анализа форм в их употреблении, сознательного построения фраз и предложений, понимания правил использования языкового материала в речи, обобщения и систематизации. Познание языковой системы особенно важно в филологической аудитории, которой приходится не только изучать, но и в дальнейшем преподавать язык.

Таким образом, актуальность исследования обусловлена вниманием ученых к проблеме преподавания русского языка как иностранного и недостаточным количеством работ, касающихся лингвистических и методических основ обучения китайских студентов русским отглагольным словосочетаниям, отсутствием учебных пособий, основанных на данном материале.

Для совершенствования грамматически правильных речевых навыков на русском языке необходимо показать функционально-семантические особенности русских падежных форм в сопоставлении с китайскими грамматическими формами, что поможет предотвратить ошибки, вызванные интерференцией, и создать комплекс упражнений для исправления и преодоления многочисленных ошибок, возникающих в речи китайских студентов, когда они смешивают значения разных падежей или значения одного падежа. Комплекс упражнений для коррекции представляет собой иерархически структурированное единство определенных видов упражнений, количество и последовательность которых предопределяется закономерностями коррекции указанных умений, относительно этапов формирования компонентов умений в разных видах речевой деятельности [7; с.127].

Созданная в исследовании методика может быть использована при обучении китайских студентов-филологов русской грамматике на основе глагольно-существительных словосочетаний с целью коррекции и последующего совершенствования продуктивных и рецептивных навыков в учебно-профессиональной сфере при обучении будущих учителей. Национально-ориентированная модель будет полезна и для обучения китайских студентов-нефилологов.

\section{ЛИТЕРАТУРА}

1. Московкин Л., 2019. Теоретические основы выбора оптимального метода обучения (русский язык как иностранный, начальный этап). СПб: СМИО-Пресс, $160 \mathrm{c}$.

2. Кулешова Н., 2017. Формирование грамматических навыков на начальном этапе в основной школе: тезисы. Краснодар, 54 с.

3. Щерба, Л., 2014. Языковая система и речевая деятельность. Лондон, 427 с.

4. Тан, А., 2018. Грамматика в китайской традиционной науке. Москва: Филологические науки, 5, с. 69-75.

5. Останенко А., 2017. Преподавание русской грамматики иностранным учащимся на начальном этапе. Москва: Русский язык, 144 с.

6. Донская, Т., 2019. Очерки методологии русского языка. Санкт-Петербург: Издательство "Сударыня", 160 с.

7. Щукин А., 2020. Методика преподавания русского языка как иностранного. Москва: Высшая Школа, 334 с. 